\title{
THE INAUGURAL MILROY ASERAPPA PAUL MEMORIAL ORATION
}

\author{
Dr. K. Yoheswaran \\ F.R.C.S. Edinburgh, F.R.C.S England
}

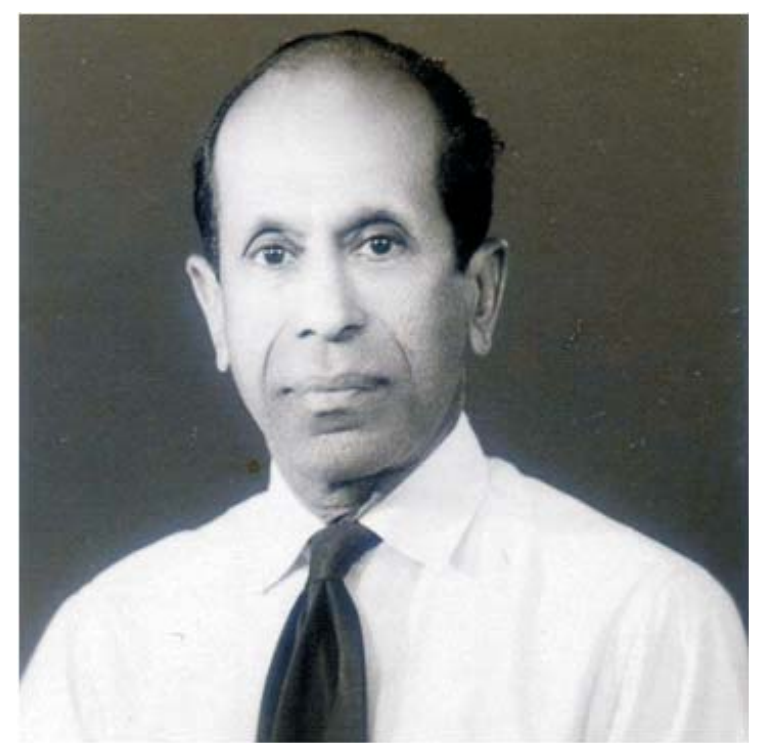

Professor Milroy Aserappa Paul, a renowned teacher, compassionate surgeon and intellectual, adorned the Colombo Medical Faculty of the University of Ceylon from 1937 to 1965 as its first Professor of Surgery. His presence in the Chair brought more encomiums to the Medical School, than the school ever conferred on him. Milroy Paul was a household name during his time. He was probably the best-known member of our profession both in this country and abroad. He was certainly the best-loved teacher in our only medical school at that time. To a smaller number, which includes the students of the Colombo Medical School, was accorded the privilege of knowing him. His contribution to our country will be treasured by generations.

At the turn of the twentieth century, Colombo was both a peaceful and a tranquil city. The roads were lined by large Acacia and Flamboyant trees, and lit by gas lamps. Dr. Samuel Chelliah Paul was a medical officer at the Colombo General Hospital and was to leave for England where he was to embark on a career in surgery. Dr. S. C. Paul had married Dora Eleanor Aserappa, the only daughter of Dr. Simon de Mellho Aserappa, the previous year.
She gave birth to her eldest child, Milroy Aserappa Paul, on the $20^{\text {th }}$ of January 1900 at their residence in Ward Place, then a new suburb known as Cinnamon Gardens. It was aptly named, being a sandy land full of cinnamon bushes, where only a few years previously, officers of the British garrison from the Fort, would of an afternoon, ride out for their sport of shooting hare.

His lineage was a strongly medical one. His paternal grandfather, Dr William Paul had qualified at the Jaffna Medical School in1864. He was a pupil of Dr. Samuel Greene, a medical missionary from Boston U.S.A, who had qualified at the Massachusetts General Hospital and came out to the American Mission in Jaffna in the early $1830 \mathrm{~s}$. He founded the Jaffna Medical School in 1840. Dr. Green's aim was to produce medical graduates who would stay in the north of Ceylon to serve the people of that area where the language used was primarily Tamil. For this purpose, he encouraged the use of Tamil in teaching. Dr Paul, in addition to his clinical work, translated the surgical texts in to Tamil and spent the rest of his life in the practice of surgery in Jaffna. Milroy's maternal grandfather was Dr Simon d'Mellho Aserappa, who was to become the Chief Medical Officer of the Colombo Municipality.

Milroy was a studious child, whose playmate and brother, Reginald, was a year younger. When he was four years old, an English governess was engaged to look after the two boys and to teach them the three " $\mathrm{R}$ "s, reading, writing and arithmetic.

Both lads, particularly Milroy, developed a lifelong skill in these fundamentals. His parents' home in Ward Place had a cultured environment with books in profusion. Their liberal education, which had a bearing in later life, was a reflection of this. In addition to his own leading role as the Senior Surgeon of the 
Colombo General Hospital, Dr. S. C. Paul had a wide range of interests. He, together with $\mathrm{Mr}$. Justin Kotelawela, founded the Ceylon Insurance Company. These two, the brothers of the De Vos family and A.T. S. Paul, the first Cardio thoracic Surgeon in Sri Lanka, grew up in considerable affluence where learning was prized above all.

His primary and secondary education were at the Training College, and later, at Royal College, both at Race Course Avenue. Ball games at school were not his forte. He was more serious minded and carried away many prizes at Royal College. His name still appears on many of the long boards in the main hall, as a heritage for the boys of future generations. At nineteen, Milroy Paul was selected for admission to the Ceylon Medical College, just a short distance from his home in Ward place. Within a year, he was granted admission at King's College and King's College Hospital in London. Cecil Wakely, who was on the consultant staff at Kings, took an interest in the studious young man from Ceylon and they developed a life-long friendship involving regular correspondence over the years. Milroy continued to display his academic prowess by enjoying great successes at examinations. He qualified with both the Conjoint Diploma and the University degree in 1925.

Being at a loose end between qualifications and assuming duties as a house surgeon in mid 1925, he enrolled in Dr. Papworth's private classes for Membership of the Royal College of Physicians (MRCP) of London. He passed the Membership at the first attempt and was now a qualified physician just assuming duties as a house surgeon. He was admitted as a Fellow of the Royal College of Surgeons (FRCS) of England in 1926, and shortly after, returned to Ceylon looking forward to a surgical career.

Prior to this only Dr. Vrasapillai Gabriel in 1920 had achieved twin postgraduate qualifications.

Soon after returning from England, Milroy married his cousin Ponmany Hannah Winifred in 1926. They had one son, Wakely, so named after his mentor at King's. She suffered from mitral stenosis, which was so incapacitating that, in her later years, she had to be carried upstairs. She died in 1944 of cardiac failure.

In 1945, he married for the second time, Irma Maheswari Tampoe Phillips, who was a niece of his senior colleague Dr. A. S. Rajasingham. They had four children, three of whom chose medicine as a career. All four of them now live abroad in Australia and the United States of America, and have achieved success in their chosen careers. Shiv antha is a practising psychiatrist in Jacksonville, Florida. Their only daughter, Shikanthini, was appointed as a Consultant Geriatrician in Australia. Amajit became a dentist, whose services are much sought after in Melbourne. Their youngest son Avinder is an accountant in Sydney. Irma was a tower of strength to Milroy. They enjoyed ballroom dancing, playing tennis and, of course, entertaining. They were great ambassadors of our country. Irma took care of Professor Paul in his retirement spent between visiting wild life parks and their children overseas. She was mainly instrumental in the relentless pursuit of setting up of this oration to commemorate this great man.

At the time of his return in 1926, Milroy found that the post of a fifth Surgeon at the Colombo General Hospital was vacant. When he applied for the post he was told by Dr. Bridges, Head of the Health Services, that he was too young and lacked experience, and was appointed as Lecturer in Anatomy instead. Two years later, the post remained unfilled, and when Milroy reapplied, was told that experience was necessary, and was appointed as Surgical Tutor without any defined duties.

A part of his duty as surgical tutor was to teach on patients scheduled for surgery the next day. $\mathrm{He}$ would anxiously await the surgical findings.This was exciting, as his training had taught him deductive reasoning, whereas the collective reasoning in Colombo was intuitive, based on experience. This work initiated him into a long and successful career as an outstanding teacher.

The following year Milroy, once again, sought the post of the fifth surgeon, but to no avail. Dr. Briercliffe, who had succeeded Dr Bridges, recommended he go back to England to obtain the Mastership in Surgery. He was overjoyed at 
this advice and returned to King's College, his alma mater, and that of his father. He soon returned to Ceylon with the added qualification under his belt and was posted as surgeon to the Civil Hospital in Jaffna from 1930 to 1933, only the third surgically qualified man to hold that post. The first Surgeon to hold this post was Dr. Kuneratnam followed by Dr. A.H.T. De Silva.

Milroy Paul held the post of fifth surgeon at the Colombo General Hospital after he completed his stint in Jaffna and, in 1937, was appointed as the first Professor of Surgery at the Ceylon Medical College. He held this post concurrently with his wards at the Colombo General Hospital and the Lady Ridgeway Hospital for Children. This was also the time when it had been determined that medical education in Ceylon should be guided by professional staff. The initial appointments were made in 1937; Dr P. B. Fernando was appointed to the Chair in Medicine, Dr. G. A. W. Wickremasuriya, who was recently awarded the Kathleen Bishop Herman of the British Medical Association for his work on malaria and pregnancy, to the Chair in Obstetrics and Gynecology and Dr. Karunaratne, whose early publications were jointly with Cameron, from University College London, in the field of cirrhosis of the liver, as the Chair of Pathology. These were all excellent and exciting appointments not merely of practitioners in their respective fields, but of men who had the drive to push the boundaries of medicine with their research and publications. They worked tirelessly and published papers in medical journals abroad, which drew attention to this newly founded medical school.

Professor Milroy Paul gave of himself wholeheartedly to his work and gave us the impression that he derived more pleasure from work than anything else in his life. He singlehandedly organized the department of surgery, setting up a work ethic, curriculum, teaching and training methods and a research program. The curriculum he set was the prototype used by every medical college in the country including the private medical college in Ragama. He set the bar high for his successors R. A. Navaratne, A. H. Sheriffdeen and N. Samarasekera.
The range of his surgery was stupendous. Western surgery was still not readily accepted in Ceylon, with the consequence that patients accepted it as a last resort, presenting for treatment at an advanced stage of disease; goitres were the size of water melons, inguinoscrotal hernias that had to be wheeled in a wheel barrow, elephantiasis of the legs and the scrotum, together with the whole range of abdominal surgery, were part of his usual repertoire. At the Lady Ridgeway Hospital for children, he enjoyed repairing cleft lips and palates, correction of exomphalos, repairing congenital intestinal obstruction, imperforate anus and emergency tracheostomy for diphtheria as part of his routine work. He was a tireless surgeon who took on challenges that other surgeons refused to touch. The debilitating and depressing problem of chronic lymphoedema of the legs serves as an example; he took on the challenge of researching and treating the condition and, having decided that Charles' operation was the best choice, spent hours operating on poor patients to bring them relief. Most students dreaded assisting at these operations as they took well over four or five hours, during which time the student had to hold up a heavy leg during most of the operation. His oration on this subject was the culmination of this intensive research and practical work.

His attitude to patient care was "always what was best for the patient". The risks of surgery were never the determining factor, only a consideration to be evaluated. He never denied any patient the opportunity to undergo surgery just because there was a high risk. There was another side to the man; when called in for an emergency operation, he would arrive within ten minutes, don his black Wellingtons and ace along the corridors to theatre often passing his students ambling along, who he would later refer to as a "Herd of buffaloes in a sea of treacle". His prudent house officer would ensure the patient and theatre were ready before he arrived and that the anaesthetist and blood bank were informed. On arrival, he would take a head count to ensure that all his students were present. Many were the tricks of impersonations by his students to make sure that the count was 
correct! He would then go through the history and physical signs with the house officer and examine the patient. The house officer may have called him in to repair a perforated peptic ulcer whereas the professor, after examination, may have disagreed with this. He would address his students and say, "Here we have a problem" "The history and findings are as follows. My house officer says it is a perforated peptic ulcer; I say it is pancreatitis. Let us now find out". The excited students dared not cross the artificial white line drawn by Lewis, his theatre attendant for many years. Lewis knew his quirks and peculiarities, and in return, was accorded the privilege of placing the patient on the table and adjusting the light appropriately. Professor Paul would commence the operation talking all the while. On this particular occasion, as he opened the peritoneal cavity, there was the tell tale hiss of escaping gas. He turned to his students and said, "My houseman has it. A perforated peptic ulcer it is"! Of course he knew it all the along but this was his way of encouraging us and making the theatre a stimulating environment. For him, all that mattered was the process of deductive reasoning and independent thinking.

Not having the benefit of modern haematological, histopathological, immunohistochemical, imaging and other facilities, his research was mainly based on observation of his surgical patients. One story that he often repeated at his lectures on head trauma was regarding extradural haemorrhage. There were two reasons that lead him to challenge the conventional belief that extradural haemorrhage from trauma to the head was from the artery and not the vein. One was that subdural haemorrhage was most often venous in origin. The second, which he had found, was the ease with which the bleeder could be stopped. Based on his findings, in 1955, he delivered a Hunterian Oration on "Haemorrhages from Head Injuries".

Milroy Paul differed with the physicians about whether there was an entity called Amoebic Hepatitis. His contention was that an early stage of amoebic liver disease was the result of several small abscesses, which later coalesced into a big one. He felt that the treatment of these small abscesses with emetine was curative. Today, with the benefit of ultra sound and computerised tomography, this is exactly what we see. Professor Paul has been quoted on this topic in Bailey and Love's 'Short Practise of Surgery'; $14^{\text {th }}$ edition, page 798.

Professor Paul contributed to prestigious medical journals published in England. Cecil Wakely, who was then on the editorial board, wrote back suggesting that Milroy's submissions were mainly on diseases prevalent in the West, and perhaps might have been increasingly seen in Ceylon, but suffered in comparison with those of his peers in England, on account of lesser investigative facilities. He suggested instead, that the latter should turn his attention to tropical diseases, of which an English readership knew next to nothing. Good advice, gratefully accepted. Thereafter, followed a spate of papers, which at the end of his career in 1965 , numbered eighty. One has to remember that his period of writing lasted 35 years beginning 1930 at a time when there were no online search facilities. One had to refer to the index medicus with its 6-point print. Also, he had to rely on reprints sent by authors from abroad. He contributed to journals in England, Australia, New Zealand, India and the USA. There was no field of surgery in which he failed to make an original contribution. His range of interests covered such diverse subjects as elephantiasis, amoebiasis, typhoid, urological problems and head injuries all of which presented as surgical problems. The writing was not merely descriptive, but evoked an intellectual curiosity as to causation. Almost invariably, they were also provocative. He didn't merely describe tropical diseases. He dissected them until he understood causation, and he frequently postulated in his presentations. It is this aspect of the man that was so highly regarded in the surgical world. Here was one of that rare breed of men - a surgical thinker. Great surgeons have abounded over the years. Surgeons, who were also good teachers, were not so common, but they existed in every country. However, surgical thinkers, who were also great teachers, were exceptional. To have been an apprentice under such a great surgical thinker must have been the highest 
accolade for an aspiring surgeon. To have understood his mental versatility was the ultimate prize.

In the course of his career he delivered the prestigious Hunterian Lecture at the Royal College of Surgeons on three occasions. To the best of my knowledge, this has not been repeated. The three lectures were entitled, The Surgical Anatomy of the Spermatic Cord in 1950, Congenital Abnormalities of the midline Abdominal Wall in 1953, and Haemorrhages from Head Injuries in 1955. He was unaffected by these achievements and remained a simple man. The story goes that, when he went to deliver his third Hunterian oration in 1955, the doorman, who mistook him for a postgraduate student, asked him if he had come to register for the postgraduate course. Milroy replied, "No, I have completed that". 'Oh", asked he doorman, "Then have you come to register for the FRCS examination"? "No, sir, I have finished that too" said Paul. Ah! "You must have come to listen to the Hunterian lecture"? "No sir" said Paul politely, "I have come to deliver it"!

By now, Milroy Paul's reputation had spread among the medical communities in most of the English speaking countries, in particular England. Young doctors from Ceylon who went to England for training in surgery were amazed at the popularity and esteem Professor Paul enjoyed. When they applied for a post, they were frequently asked "Do you know Professor Milroy Paul? If replied "I was his house surgeon, the next question, to the delight of the candidate, was "When could you start". On another occasion, a consult surgeon on sabbatical from Ceylon was appointed as a locum consultant in an English Hospital. On his first day, he was faced with an operating list in which there was a patient with obstructive jaundice. The pre-operative diagnosis was stones in the common bile duct. Though he disagreed with this, he proceeded with the surgery and found the cause of jaundice was due to a carcinoma of the ampulla of Vater. The operation continued with a partial pancreatectomy. Unknown to the surgeon, this incident had been the subject of conversation in the Consultants' Room. Three days later, in the hospital, a gentleman stopped him and asked
"Are you the surgeon from Ceylon who performed the Whipple operation? The reply was in the affirmative. The gentleman introduced himself as a retired consultant in the hospital and went on to ask "Do you know Professor Milroy Paul? "I was his house surgeon" said the locum. "I knew it! I told them you must be one of Paul's trainees" said the retired surgeon. He went on to say that Professor Paul was a popular visitor to their hospital and that they often hosted him to dinner mainly to hear his delightful after dinner speeches.

At the time, surgeons travelling between England and Australia on the Orient Lines, which regularly stopped in Colombo, would take the opportunity to visit Professor Paul. They would attend ward rounds and operating sessions, and at times, would be asked to demonstrate operations of their preference. I recall Sir Cecil Wakely and Sir John Nicholston, two such visiting surgeons. It was not unusual for these surgeons to be hosted to dinner by Irma and Milroy at Rao Mahal.

While known far and wide for his skills and innovation in the field of surgery, it is his research and teaching that truly defines the legacy of Milroy Paul. He challenged current thinking and theories in those early days. He brought in a breath of fresh air and originality into the thinking process on both medical and non-medical topics, which inspired us, his students, to think outside the box. Teaching was his forte and his classroom his stage. It was a performance we wouldn't miss for anything. He was a brilliant teacher who never repeated what was in textbooks. Rather, he had his own theories on the causation, management and natural history of a disease, at times to the astonishment of some of the students who had memorized the textbooks. Didactic teaching and learning by rote had no place in his classroom. Whatever it was, his lecture halls were always crowded and his teaching sessions in the ward were always overflowing with students. Latecomers often found they were crowded out. Which of his students would forget his Saturday morning ward teaching sessions for the final year students? Students would cling onto the window sills and hang by the windows 
reminiscent of the overcrowded buses we see today to get a glimpse of the professor and hear pearls of surgical wisdom from his lips. "Look at this chappie", "Get moving man!" or "You are fired" were some of his favourite expressions which were followed by remarks on a student's performance, thereafter followed by laughter from the student's peers. These words were never meant to hurt but rather to encourage. In fact, most students considered it to be an honour to be insulted by the great professor and they would boast about it at the faculty canteen over a cup of tea. He also had an open house for any student to attend the clinical demonstration on a Saturday morning. The usual custom was for a surgical student to present a hitherto undiagnosed patient giving both history and physical signs. From then on, the professor would proceed by a process of deductive reasoning and finally arrive at a diagnosis. Carlo Fonseka, now a retired Professor of Physiology, then just a medical student, thought this performance was highly theatrical and decided to present the same patient over a course of two weeks, confident that the professor would not remember. To his absolute delight, the professor arrived at a different diagnosis on the second occasion. Putting on his grandest manner, young Carlo then said, "Sir, this patient was presented last week and you made a different diagnosis. How would you explain that, Sir"? Unabashed, Milroy promptly replied to the delight of the assembled throng, "Science marches on man. Carlo, you are left standing where we were last week". Witticisms such as this were commonplace on Saturday mornings. It would not be an exaggeration to say that the surgical demonstration on a Saturday morning was probably the highlight of a student's week.

Though a disciplinarian with a stern exterior, Professor Paul was fair when examining final year students. Dr. M. H. de Zoysa, one of his former registrars, tells the story of a candidate having misdiagnosed a patient with rectal cancer from Badulla as having haemorrhoids (piles). Professor Paul had given him the minimum pass mark! After the examination Dr. Zoysa asked the professor why he gave the candidate a pass mark. The reply had been "I say Zoysa, when I asked him what he would do, the candidate said he would refer him to the local surgeon. Now, the surgeon in Badulla is Dr. Sivagnanam, one of the finest in this country. Surely, he would not miss the diagnosis?" If the student had suggested a treatment, he most certainly would have failed. For 32 years Professor Paul continued to teach successive generations of medical students, and I think I speak for every one of them, when I say they all enjoyed his classes.

Professor Paul belonged to many medical societies both at home and abroad. He never talked about it, and few knew of it, but he had membership at a few elite surgical clubs and societies in England that were exclusive to those who had made significant contributions in the field of surgery. The Moynihan Club in Leeds and the prestigious James the Fourth surgical club come to mind. The latter has only twenty-five members and a next prospective appointee has to await the demise of one of its members. Professor Paul was conferred membership in this esteemed society for his prolific contributions to surgical literature. In the mid nineteen sixties, an Arthur Sims Travelling Professor referred to him as the bestknown surgeon in the British Commonwealth. He was conferred an honorary fellowship of the Association of Surgeons of Great Britain and Ireland and was a founder fellow of the International College of Surgeons.

At home, he founded the Association of Surgeons of Sri Lanka in the 'nineteen sixties', which, in the course of time, gave way to the College of Surgeons of Sri Lanka. Today, we honour Professor Milroy Paul at this inaugural lecture under the auspices of the College of Surgeons of Sri Lanka. He also founded the Sri Lanka Association for the Advancement of Science and held the Chair of the Sri Lanka Medical Association and was President of the Sri Lanka National Academy of Sciences. He was honoured by every university in the country with an honorary doctorate in science, and the College of Surgeons of Sri Lanka admitted him to its roll of honorary fellows. Professor Paul was also appointed as the Registrar of the Ceylon Medical Council when Dr. Startrup retired in 1942 and remained in the post until 
1982. In 1937, he was one of the founders of the Medico-Legal Society of Ceylon, together with Sir Sydney Abraham, Chief Justice, Lalitha Rajapakse, lawyer, Dr. Sinnadurai, Judicial Medical Officer, Drs. Wijerama and Sir Nicholas Attygale. The society remains active and its members continue to present numerous papers at the affiliated body, the Asia Pacific MedicoLegal Society. He also joined the volunteer regiment of the Ceylon Medical Corp. rising to the rank of Major. He served in the Army during the second World War, and resigned his commission shortly after due to the pressure of work.

One of his most endearing features was his interest in young surgeons; of what they were doing and, most importantly, if they were writing in scientific journals. Of his more recent assistants, were Dr. Henry Nanayakkara, Dr. Ananda Soysa, Dr. Norman Fernando, Dr. Rasaiah, Malinga Fernando, Dr. M. H. de Zoysa, Dr. Douglas Wickramasinghe, Dr. Michael
Abeyratne and Dr. Ranjit Silva, many of who kept in touch even after his retirement. He was particularly pleased when any one of them followed in his footsteps and became surgeons. After his retirement, he continued to visit the medical library regularly. Even after blindness overcame him, his continued interest in matters medical would see him attend many of the lectures of the Sri Lanka Medical Association, often supported by either Dr. M.H.de Zoysa or Dr. Douglas Wickramasinghe.

Generations of Colombo medical students, and I was one of them, have had the privilege of learning from him. I was more fortunate than most, for, I was his House Surgeon as were some of you in the audience today. I learnt an enormous amount from him, all of which has stood me in good stead in my career. If I were to summarize the cardinal qualities this great surgeon subconsciously passed on to me, they would be humility, honour, integrity, compassion and the ability to indulge in deductive reasoning.

\section{About the Orator \\ Dr. Kanapathipillai Yoheswaran MBBS, FRCS (Edin), FRCS(Eng).}

- Graduated from the Colombo Medical School with distinctions in Pathology, Public Health, Parasitology and in Medicine and first in the order of merit at the Final MBBS in 1955.

- 1957 he was successful at the primary FRCS, and subsequently passed the FRCS examinations Edinburgh and England in 1962.

- Resident surgeon General Hospital, now National Hospital of Sri Lanka, Colombo.

- Distinguished career as consultant surgeon at Rathnapura, Badulla, Kurunegala and Colombo South and later as a senior surgeon National Hospital of Sri Lanka.

- 1970 - Colombo plan scholarship for training in Cardiothoracic surgery at the BromptonHospital, London and PapworthHospital in Cambridge.

- 1986 - Visiting researcher at the Department of Surgery and Urology of the School of Medicine at Keio University, Tokyo.

- Handpicked as the first senior surgeon at the newly built Sri Jayawardenapura postgraduate Teaching Hospital where he served for over 10 years prior to his retirement.

- Special interest in hepato-pancreato-biliary surgery and has a large series of patients who underwent porto-caval shunting for portal hypertension, Whipple's operation;

- Another special interest of his was oesophageal surgery for cancer and strictures;

- In paediatric surgery, he has a large series of patients operated for cleft palate and lip, imperforate anus and urological abnormalities.

- He has taught many undergraduates and postgraduates and his training post in surgery was much sought after by trainees.

- He strived to instil in his trainees professionalism and etiquette, which he demonstrated in exemplary manner in every aspect of his life throughout his career.

- Awarded the VidyaJyothi Presidential and VidyaPrasadini Prime Minister's medals for his services to the country.

- Awarded university colours for volleyball and soccer.

- Special interests are reading especially Sri Lankan history and sports. 